\title{
Distribution and synchronized massive flowering of Sasa borealis in the forests of Korean National Parks
}

\author{
Soyeon Cho, Youngjin Kim and Yeonsook Choung ${ }^{*}$ [D
}

\begin{abstract}
Background: Genus Sasa, dwarf bamboos, are considered to be species that lower biodiversity in the temperate forests of East Asia. Although they have a long interval, they, the monocarpic species, have a unique characteristic of large-scale synchronized flowering. Therefore, once they have flowered and then declined, it may be an opportunity for suppressed surrounding species. A previous study reported that Sasa borealis showed specialized flowering nationwide with a peak in 2015. However, this was based on data from a social network service and field survey at Mt. Jeombong. Therefore, we investigated S. borealis in the forests of five national parks in order to determine whether this rare synchronized flowering occurred nationwide, as well as its spatial distribution.

Results: We found a total of 436 patches under the closed canopy of Quercus mongolica-dominated deciduous forests in the surveyed transects from the five national parks. Of these patches, $75 \%$ occupied a whole slope area, resulting in an enormous area. The patch area tended to be larger in the southern parks. Half (219 patches) of the patches flowered massively. Among them, 76\% bloomed in 2015, which was consistent with the results of the previous report. The flowering rate varied from park to park with that of Mt. Seorak being the highest. The culms of the flowering patches were significantly taller $(F=93.640, p<0.000)$ and thicker $(F=61.172, p<0.000)$. Following the event, the culms of the flowering patches declined, providing a good opportunity for the suppressed plant species. The concurrent massive flowering of the mature patches was believed to be triggered by some stress such as a spring drought.

Conclusion: We confirmed that the rare synchronized flowering of S. borealis occurred with a peak in 2015 nationwide. In addition, we explored that $S$. borealis not only monopolized an enormous area, but also dominated the floors of the late-successional Q. mongolica-dominated deciduous forests. This presents a major problem for Korean forests. As it declined simultaneously after flowering, there are both possibilities of forest regeneration or resettlement of $\mathrm{S}$. borealis by massively produced seeds.
\end{abstract}

Keywords: Dieback, Forest dynamics, Mass flowering, Semelparous reproduction, Simultaneous flowering

\section{Background}

Qian and Ricklefs $(1999,2000)$ stated that the Eastern Asian phytogeographic zone, which includes the Korean peninsula, belongs to one of the highest diversity groups within the world's temperate forests. For example, the forest flora of the Korean Peninsula is more diverse than that of comparable forests in Europe and North America (Qian and Ricklefs 2000).

\footnotetext{
* Correspondence: yschoung@kangwon.ac.kr

Department of Biological Sciences, Kangwon National University, Chuncheon 24341, South Korea
}

However, the Genus Sasa, dwarf bamboos, is widespread and dominant in the lower strata of the East Asian forests. They have been known to be species that inhibit species diversity and tree regeneration (e.g., Nakashizuka and Numata 1982; Ito and Hino 2007; Cerny et al. 2013, 2015). Cho et al. (2018) reported that plant species diversity was significantly reduced with the dominance of Sasa borealis in the forests of Gangwon Province, Korea. Due to the clonal growth habit, it forms a dense mono-stand that physically occupies the aboveground and underground spaces and lowers the light intensity reaching the floor (Wada 1993; Park et al. 2012).

(c) The Author(s). 2018 Open Access This article is distributed under the terms of the Creative Commons Attribution 4.0 International License (http://creativecommons.org/licenses/by/4.0/), which permits unrestricted use, distribution, and 
Moreover, it has a long life span (Makita 1998) and slow decomposition rate (Narukawa and Yamamoto 2002). Although it is a native species, it exhibits characteristics similar to invasive species.

Clonal plants, such as Sasa species, rapidly expand horizontally without a suitable pollinator. With their high morphological plasticity, they adapt well to environmental stress (Harper 1977). Moreover, their high shade tolerance makes them capable of invading stable mature forests in China. For example, Moso bamboo (Fargesia decurvata), a dwarf bamboo, has invaded a fir forest (Liu et al. 2011), mixed forests (Shen et al. 2016), and evergreen broad-leaved forests (Yang et al. 2011). Even dominant species have been changed (Hong et al. 2004). In addition, the shoot can grow fast, reaching its maximum height within 70 days, with support from the underground rhizome.

Sasa borealis is a native species that is very widespread throughout Korea (Lee and Lim 2002). Cerny et al. $(2013,2015)$ studied forest vegetation, including national parks in Korea, and stressed that the dominance of $S$. borealis is the most important factor hindering the succession of the Korean forests. Further, it is possible that S. borealis is controlled naturally. Many bamboo species have distinctive flowering characteristics. After about 10 to 100 years of vegetative growth, most of the genets flower simultaneously and decline (Janzen 1976; Taylor and Zisheng 1988; Makita 1992). Although it is not easy to observe the flowering events because of the long intermast intervals, synchronized flowering and dieback of the Sasa species have also been reported (e.g., Makita 1998). The simultaneous decline following the flowering of $S$. borealis contributed to the regeneration of the suppressed plants (Nakashizuka 1988).

Recently, Cho et al. (2017) reported that nationwide synchronized flowering of $S$. borealis occurred at its peak in 2015 in Korea. This study was meaningful insofar as being the first study revealing the rare flowering event of $S$. borealis in South Korea. Aside from a direct field survey of Mt. Jeombong, most information was based on the social network service recorded by mountain visitors. Because national parks are popular places, it is possible that several observers will record the flowering phenomenon in the same place.

Nationwide massive flowering of $S$. borealis is very rare. If it withers within a short time after the flowering, it could then be a significant influence on the dynamics of the forest occupied by the species. Therefore, we investigated the flowering and decline events of $S$. borealis along with the spatial distribution in the forests of five national parks.

\section{Methods}

\section{Studied national parks and investigated transects}

Most national parks in South Korea are located along the great mountain range, Baekdudaegan, from north to south. Among the national parks, Mts. Seorak, Odae, Sobaek, Deogyu, and Jiri were selected (Fig. 1) and surveyed in the summer of 2017. A total of 25 transects (trails) were set considering the park area and distribution of S. borealis (Table 1). In total, $133.5 \mathrm{~km}$ from the transects was surveyed. The distance of each transect varied according to its topography. The topography of Mt. Seorak was more complicated than that of the other mountains. The northern part was steep, while the southern part, where Mt. Jeombong is located, was gentle. Therefore, we surveyed the longest distance of $34.9 \mathrm{~km}$ in Mt. Seorak National Park. Mts. Odae, Sobaek, and Deogyu were each explored by four transects. Mt. Jiri, the largest park area, was explored by five transects with a distance of $31.2 \mathrm{~km}$. The annual precipitation and temperature were high with more rainfall in the southern parks, reflecting the effects of the latitude (Fig. 1; Korea Meteorological Agency 2017).

\section{Vegetation survey and data analysis}

We investigated all transects from the trail starting point at low regions climbing toward the higher ones, such as ridges or tops. In each transect, all of the patches of S. borealis on both sides of the trails were surveyed. A patch was defined as an area where $S$. borealis grew densely and could be visually distinguished from the surrounding area. Each patch size was divided into four classes: $\leq 100 \mathrm{~m}^{2}$, $100 \sim 1000 \mathrm{~m}^{2}, 1000 \sim 2500 \mathrm{~m}^{2}$, and whole slope. The

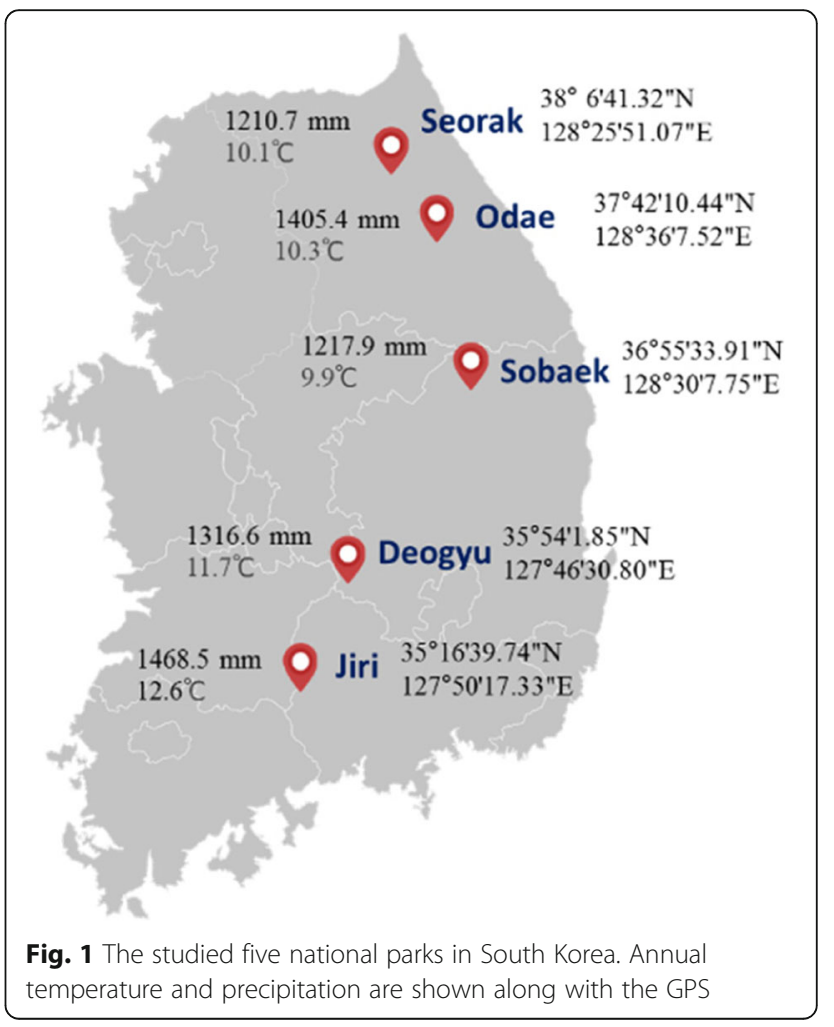


Table 1 Investigated transects and the distances in five national parks

\begin{tabular}{|c|c|c|}
\hline National park (area) & Transect & Distance $(\mathrm{km})$ \\
\hline \multirow[t]{8}{*}{ Seorak $\left(398 \mathrm{~km}^{2}\right)$} & Seorakdong Park Information Center-Sinheungsa-Biseondae & 3.0 \\
\hline & Hangyeryeong Resting Place-Hangyeryeongsamgeori-Gwittegicheongbong & 2.8 \\
\hline & Osaek Ranger Station-Seonnyeotang-Geumgangmun-Yongsopokpo & 3.2 \\
\hline & Seorakdong Park Information Center-Yukdampokpo-Biryongpokpo-Towangseongpokpo Observation & 2.8 \\
\hline & Pilryeyaksu-Mangdaeamsan (Mt. Jeombong) & 0.9 \\
\hline & Gangseon Village-Gombaeryeong (Mt. Jeombong) & 8.1 \\
\hline & Ganeungol-Danmokryeong (Mt. Jeombong) & 7.0 \\
\hline & Garimakgol-Saeyanggol (Mt. Jeombong) & 7.1 \\
\hline \multirow[t]{4}{*}{ Odae $\left(326 \mathrm{~km}^{2}\right)$} & Sangwonsa-Horyeongbong & 1.7 \\
\hline & Sangwonsa-Woljeongsa & 8.1 \\
\hline & Jingogae-Dongdaesan-Dongpigol & 4.4 \\
\hline & Sinsungol & 0.9 \\
\hline \multirow[t]{4}{*}{ Sobaek $\left(322 \mathrm{~km}^{2}\right)$} & Eouigok Park Information Center-Birobong & 4.8 \\
\hline & Eouigok Park Information Center-Sangwuelbong & 4.5 \\
\hline & Jungnyeong Park Information Center-Yeonhwabong-Huibangpokpo & 9.5 \\
\hline & Jungnyeong Resting Place-Dosolbong & 5.9 \\
\hline \multirow[t]{4}{*}{ Deogyu $(229$ km²) } & Gucheondong Park Information Center-Hyangjeokbong & 7.0 \\
\hline & Yeonggak Park Ranger Post-Namdeogyusan-Wolseong Park Ranger Post & 8.4 \\
\hline & Gucheondong Park Information Center-Sindae Resting Place-Baengnyeonsa-Hyangjukbong & 7.8 \\
\hline & Hwangjeom Park Ranger Post-Satgatbong & 4.4 \\
\hline \multirow[t]{5}{*}{ Jiri $\left(483 \mathrm{~km}^{2}\right)$} & Seonggamjae Ranger Station-Nogodan & 2.1 \\
\hline & Eumjeong-Yeonhacheon Shelter-Hyeongjebong-Byeoksoryeong Shelter & 12.1 \\
\hline & Jungsanri Visitor Center-Cheonwangbong & 5.4 \\
\hline & Yeongwonsa-Sambulsa & 6.3 \\
\hline & Jungsanri Visitor Center-Jeseokbong & 5.3 \\
\hline Total & & 133.5 \\
\hline
\end{tabular}

'whole slope' referred to cases where one patch covered the entire slope, or the patch continued to cover other slopes, making it difficult to estimate the area.

For each patch, the presence of inflorescences was examined then classified into "flowering" and "non-flowering" patches. The flowering time of a flowering patch was identified empirically according to the state of the inflorescence. Inflorescences flowered in 2017 (referred to as "2017F") had a vivid purple flower at the time of the survey. Those that flowered in 2016 (2016F) remained only as florets without fruits, and most of their leaves withered. Those flowered in 2015 (2015F) showed signs of inflorescence, but all of the florets were gone and their leaves were completely dried. Some of the patches showed signs of flowering before 2015. Even though we assumed that this had happened in either 2013 or 2014, it was difficult to exactly specify the time of occurrence. In that case, we assigned it to "pre-2015F." The "non-flowering" patches indicate those with no signs of flowering. When only a few culms had inflorescences within a patch, it was designated as a non-flowering patch. Within each patch, a $50 \times 50 \mathrm{~cm}$ plot was set up. Culms were identified as alive, declined, or flowered, then tallied respectively. The shoot heights and basal diameters of the five culms were measured.

The differences in culm density and size in accordance with the flowering state were analyzed by a randomized block design analysis of variance (ver. 23, SPSS 2016). The national park was assigned as a block source. The effects of density, thickness, and height on flowering absence or presence, respectively, were analyzed. For the flowering, 2015F, 2016F, and 2017F were pooled, and pre-2015F was excluded from the analysis. The early-flowered culms were likely to be relatively drier; thus, the height or diameter of the culms may be underestimated.

In each forest, the locations of patches were divided into four layers: tree $(\geq 8 \mathrm{~m}$ in height), subtree $(5 \sim 8 \mathrm{~m})$, shrub $(1 \sim 5 \mathrm{~m})$, and herb layers. The coverage of each layer was estimated visually, and the vegetation type was 
identified. The elevation and slope were measured, and the topography was recorded.

For spring precipitation, those from Inje, Hongcheon, Bonghwa, and Geochang Counties were used for Mts. Seorak, Odae, Sobaek, and Deogyu, respectively (Korea Meteorological Agency 2017). For Mt. Jiri, the mean value of Sancheong and Namwon was used.

\section{Results}

\section{Distribution of S. borealis}

In total, $436 \mathrm{~S}$. borealis patches were found from five national parks, with $44.5 \%$ distributed in Mt. Seorak. Among all patches, $75 \%$ were large enough to cover the entire slope. They were found at elevations ranging from 188 to $1618 \mathrm{~m}$. This indicates that this species could grow from low to high tops (Table 2). The patches were also found on gentle to steep slope areas, even though it showed poor growth in steeper slope areas. They were more common in lower slope areas and near valleys. This trend held for all five national parks.

S. borealis occurred at the forest floor of the closed canopy mainly dominated by Quercus mongolica and mixed with other late-successional deciduous trees, such as Acer, Tilia, Carpinus, and Fraxinus. In some stands, especially on Mt. Jiri, Q. mongolica exclusively dominated. On the other hand, Abies holophylla was dominant and mixed with deciduous trees above, including Q. mongolica on Mt. Odae. This also occurred in the Larix leptolepis plantations for a few patches on Mt. Sobaek.

\section{Synchronized massive flowering of $S$. borealis}

We found 50\% flowered patches out of the total 436 patches (Fig. 2). Among the five national parks, Mt. Seorak had the highest flowering rate of $74 \%$. The flowering rates of Mts. Odae and Jiri were $49 \%$ and $37 \%$, respectively. By contrast, those of Mts. Sobaek and Deogyu were $3 \%$ and $18 \%$, respectively. In $2015,76 \%$ of flowering patches were bloomed (Fig. 3). Specifically, it happened in all five national parks, unlike in the other years. Additionally, more patches bloomed in 2015, with the exception of Mt. Deogyu. In 2017, there were 13 and 10 flowering patches in the southern parks of Mt. Jiri and Mt., respectively.

Within patches, over $90 \%$ of the culms bloomed at pre-2015F to 2016F patches, and the rate was lower in 2017F patches (Fig. 4). In the three mountains of Mts. Seorak, Jiri, and Deogyu, some culms (0.9\%) flowered from the non-flowering patches. This phenomenon was found to be more common along paths with sunlight.

Table 2 Distribution of S. borealis, site characteristics, and vegetation layer structure of the surveyed plots from the five national parks

\begin{tabular}{|c|c|c|c|c|c|c|}
\hline Properties & & Seorak & Odae & Sobaek & Deogyu & Jiri \\
\hline \multirow{6}{*}{$\begin{array}{l}\text { S. borealis } \\
\text { patches }\end{array}$} & No. of patches found & 202 & 41 & 32 & 71 & 90 \\
\hline & Patch size $\left(\mathrm{m}^{2}\right)$ & & & & & \\
\hline & Whole slope (\%) & $67^{(1)}$ & 85 & 91 & 94 & 67 \\
\hline & $1000 \sim 2500(\%)$ & 8 & 0 & 0 & 0 & 2 \\
\hline & $100 \sim 1000(\%)$ & 16 & 5 & 3 & 3 & 7 \\
\hline & $\leq 100(\%)$ & 9 & 10 & 6 & 3 & 24 \\
\hline \multirow[t]{6}{*}{ Vegetation } & Type & $\begin{array}{l}\text { Quercus mongolica- } \\
\text { dominated } \\
\text { deciduous forest }\end{array}$ & $\begin{array}{l}\text { Abies holophylla } \\
\text { mixed deciduous } \\
\text { forest }\end{array}$ & $\begin{array}{l}\text { Quercus mongolica- } \\
\text { dominated } \\
\text { deciduous forest }\end{array}$ & $\begin{array}{l}\text { Quercus mongolica- } \\
\text { dominated } \\
\text { deciduous forest }\end{array}$ & $\begin{array}{l}\text { Quercus mongolica- } \\
\text { dominated } \\
\text { deciduous forest }\end{array}$ \\
\hline & Layer structure & & & & & \\
\hline & Tree layer (\%) & $91.7 \pm 0.4$ & $90.4 \pm 1.0$ & $89.6 \pm 1.3$ & $90.1 \pm 1.2$ & $85.2 \pm 1.4$ \\
\hline & Subtree layer (\%) & $32.9 \pm 1.3$ & $40.8 \pm 3.2$ & $36.1 \pm 3.2$ & $47.2 \pm 2.8$ & $58.4 \pm 2.3$ \\
\hline & Shrub layer (\%) & $29.6 \pm 1.3$ & $26.1 \pm 2.0$ & $27.2 \pm 2.2$ & $33.1 \pm 2.1$ & $32.6 \pm 1.3$ \\
\hline & Herb layer (\%) & $65.2 \pm 2.6$ & $86.7 \pm 2.8$ & $90.8 \pm 2.0$ & $94.3 \pm 1.0$ & $91.6 \pm 0.5$ \\
\hline \multirow[t]{6}{*}{ Site } & Elevation (range, m) & 188-1097 & $672-1172$ & $741-1317$ & 634-1610 & $630-1618$ \\
\hline & Slope (range, ${ }^{\circ}$ ) & $5-50$ & $5-35$ & $10-60$ & $5-60$ & $0-70$ \\
\hline & Topography & & & & & \\
\hline & $\begin{array}{l}\text { Valley and lower } \\
\text { slope (\%) }\end{array}$ & $72^{(2)}$ & 73 & 50 & 39 & 48 \\
\hline & $\begin{array}{l}\text { Upper and middle } \\
\text { slope (\%) }\end{array}$ & 16 & 27 & 38 & 34 & 33 \\
\hline & Ridge and top (\%) & 13 & - & 13 & 27 & 19 \\
\hline
\end{tabular}

(1) Relative frequency of each patch size within a park. In Mt. Seorak, frequency was calculated except for eight missing patches

(2) Relative frequency of each topography within a park 


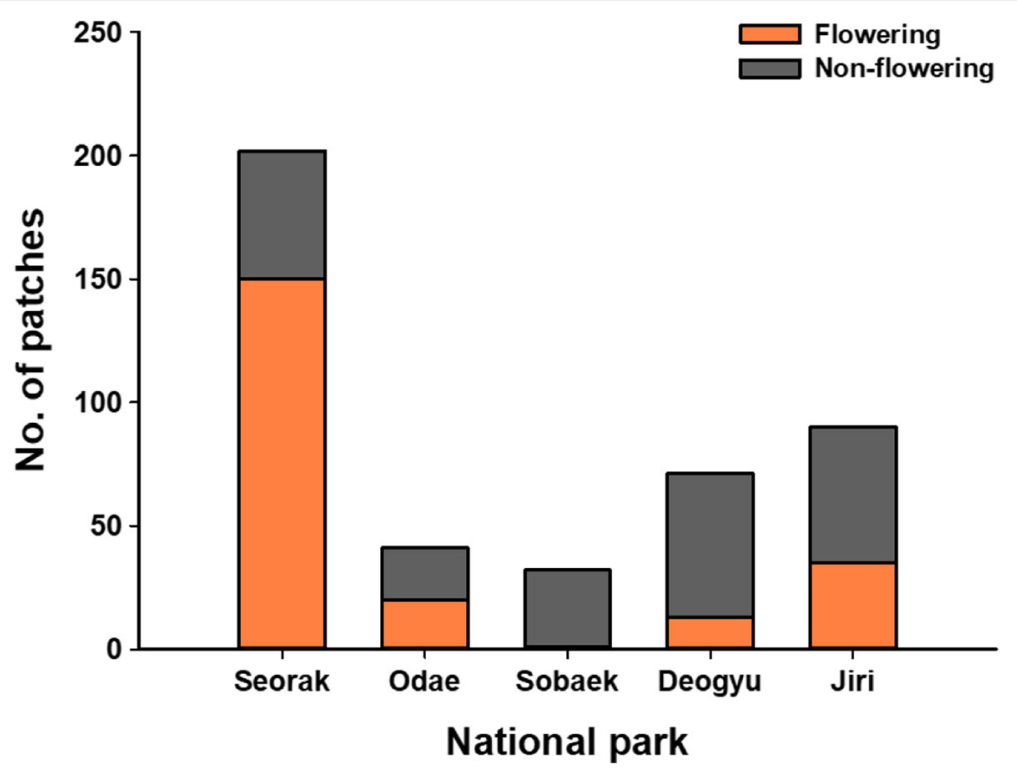

Fig. 2 Flowering rate of S. borealis patches in five national parks

The densities, heights, and diameters of culms were significantly different among the national parks (Table 3). The culm densities of the northern mountains of Mts. Seorak and Odae were higher. By contrast, those of the southern mountains of Mts. Jiri and Deogyu were lower. The size was larger for the latter two mountains. The culm density was shown to be lower at the flowering patches. However, they were not significantly different from the non-flowering patches $(\mathrm{F}=0.675, p=0.412$, Fig. 5). On the other hand, the culm height and thickness were significantly taller $(\mathrm{F}=93.640, p<0.000)$ and thicker $(\mathrm{F}=61.172, p<0.000)$ at the flowering patches. This indicates that larger culms flowered.
The spring precipitation from February to May was considered to be one of the potential factors influencing the flowering, according to Cho et al. (2017) (Fig. 6). 2015, the most flowered year, experienced a drought in springtime. In particular, those of Mts. Seorak and Odae were only $61 \%$ and $62 \%$ of the average precipitation for 30 years, respectively. Moreover, in 2014, the spring rainfall was only $53 \%$ and $41 \%$, resulting in a cumulative drought consecutively. Unlike the two mountains in the north, those of Mts. Deogyu and Jiri were 91\% and 95\%, respectively, and did not suffer drought. Therefore, the high flowering rates of the two mountains in the north in 2014 and 2015 may have been related to the spring drought. In the

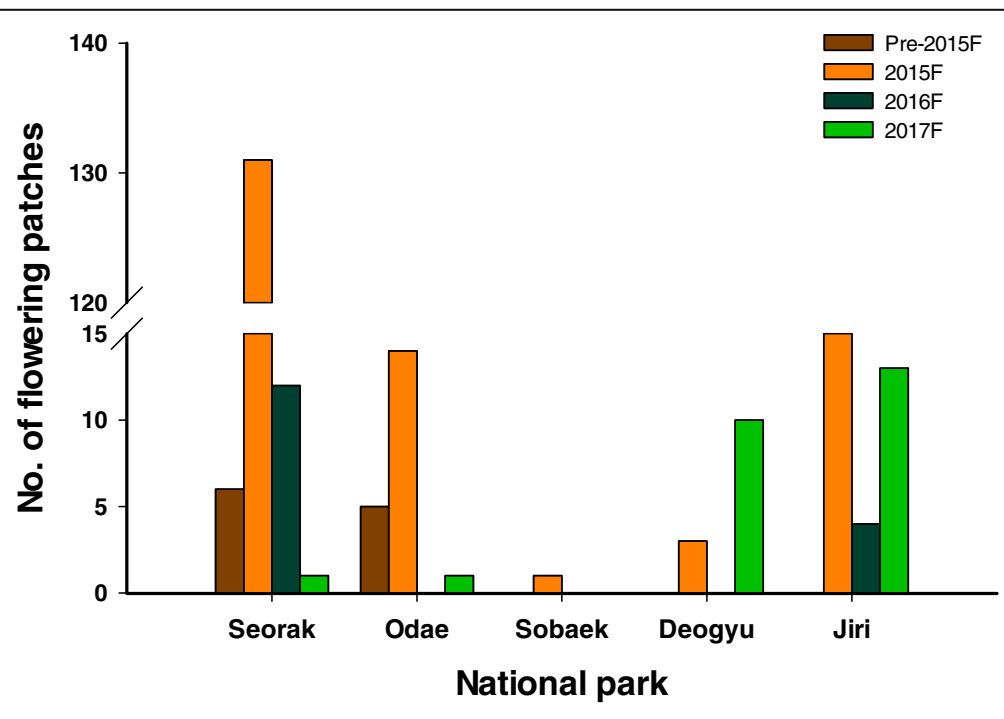

Fig. 3 Flowering time of S. borealis patches in five national parks 


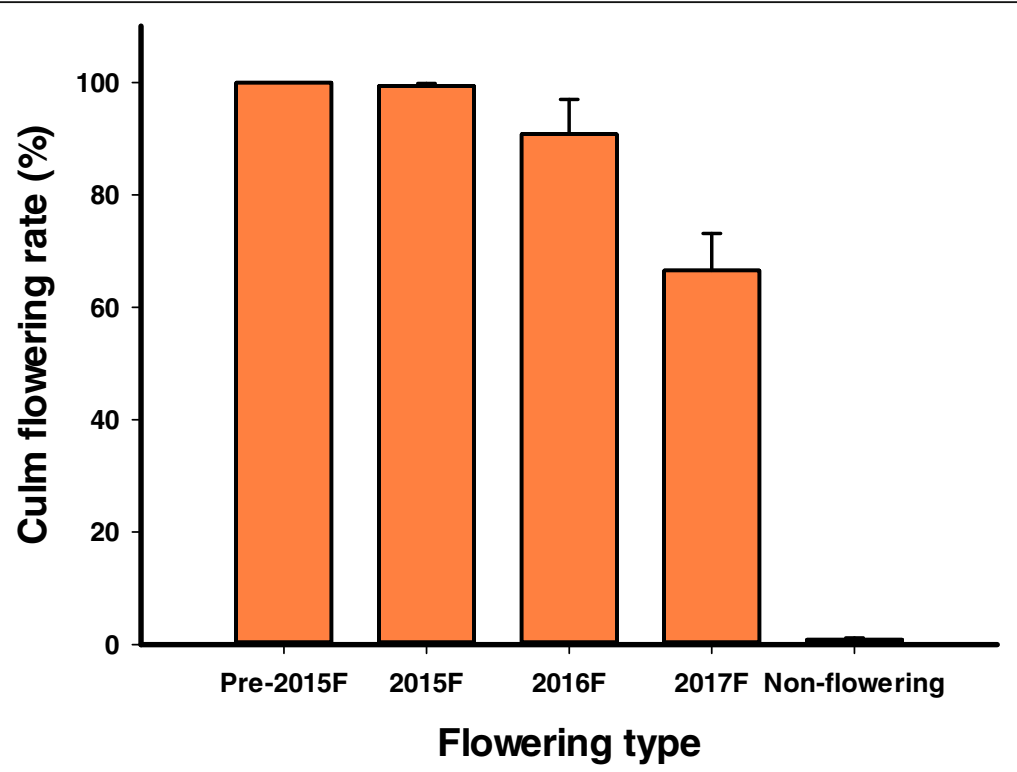

Fig. 4 Culm flowering rate in five national parks. Values are means \pm standard errors

spring of 2017, there was a spring drought again and more patches flowered in the southern two parks.

\section{Synchronized dieback following the flowering events of $S$.} borealis

Over $99 \%$ of the culms in the pre-2015F and $2015 \mathrm{~F}$ patches declined after flowering. We observed that the culms were declining immediately after flowering and completely died in Mt. Jeombong within 1 year (Cho et al. 2017). Compared to this, that of the culms in the 2016 F patches was lower at $80.7 \%$. $15.6 \%$ of culms had also declined in the non-flowering patches (Fig. 7).

\section{Discussion}

We found 436 patches of S. borealis in the investigated transects of the five national parks. The distribution area and dominance were more important than the patch number in that it occupied enormous slope area. Of the

Table 3 Analysis of variance for culm density, height and diameter according to the flowering status by randomized block design

\begin{tabular}{lccc}
\hline Source & $\mathrm{df}$ & F value & $p$ value \\
\hline Culm density & & & \\
National park & 4 & 5.781 & 0.000 \\
Flowering type & 1 & 0.675 & 0.412 \\
Culm height & & & \\
$\quad$ National park & 4 & 22.685 & 0.000 \\
Flowering type & 1 & 93.640 & 0.000 \\
Culm diameter & & & \\
National park & 4 & 12.751 & 0.000 \\
Flowering type & 1 & 61.172 & 0.000 \\
\hline
\end{tabular}

S. borealis patches we found, $75 \%$ were huge, as they tended to cover the entire slope. Most of the patches were estimated to be several tens of ha. In one transect going up to the highest peak of Mt. Jiri, a patch covered a path from an elevation of $800 \mathrm{~m}$ to $1600 \mathrm{~m}$, about $2.5 \mathrm{~km}$ long. Similar cases were also observed in Mts. Deogyu (from 600 to $1400 \mathrm{~m}, 2.4 \mathrm{~km}$ long) and Sobaek (from 870 to $1100 \mathrm{~m}, 1.4 \mathrm{~km}$ long).

Consistent with the results of Cho et al. (2018), it was distributed mainly in the late-successional forests where Q. mongolica dominated. In fact, S. borealis flourishes as if there are virtually no limitations. There is little information on how this species expands and flourishes. It could be presumed that this is because of its reduced use. Instead, Yamamoto et al. (1995) reported that Sasa spread was related to large-scale natural disturbances, such as landslides. Until the 1970s, large-scale disturbances in forests, including slash-and-burning, intensive forest use, and frequent forest fires, were presumed to be the leading causes of expansion. However, it is also possible that it could expand in a stable forest as well. According to two permanent plot studies, the frequency and abundance of $S$. borealis have increased in Mts. Gyebang (Cheon et al. 2014) and Odae (Choung et al. unpublished) over the prior 10 years.

Half of all $S$. borealis patches were found to have flowered within a few years of this study. Specifically, $76 \%$ of the flowering patches bloomed in 2015, consistent with the findings from the SNS information and some observations (Cho et al. 2017). The massive flowering of Sasa plants has been extensively studied and reviewed in Japan (Makita 1998). This is because in Japan, there are more kinds of bamboo than Korea, and the distribution 

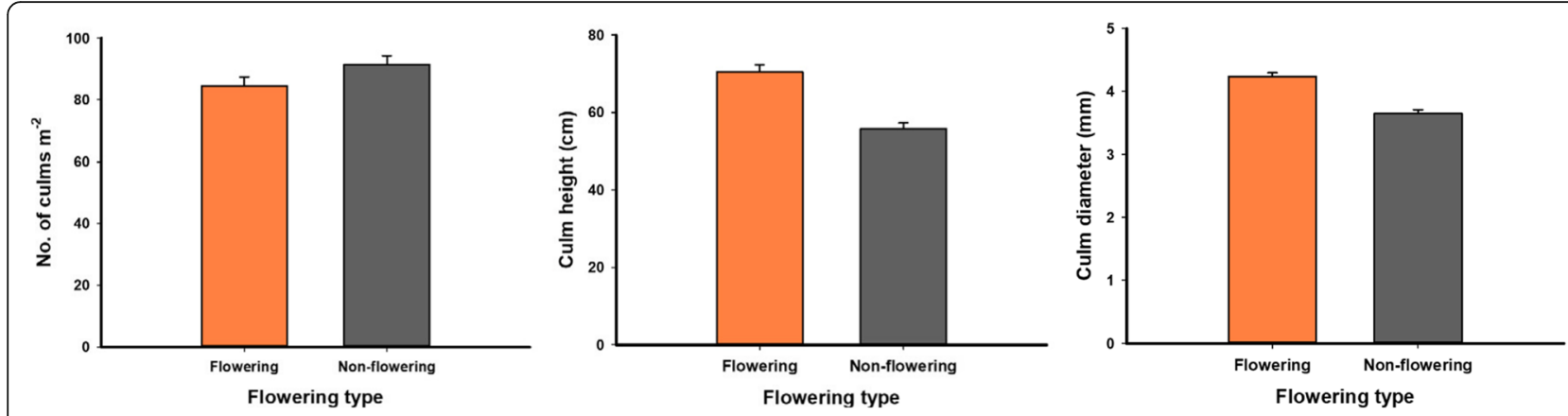

Fig. 5 Culm density and size by flowering type. Values are means \pm standard errors

area is wide. Oshima (1961) stated that it covered approximately $50 \%$ of the national parks in Japan and accounted for over $90 \%$ of the distribution in Hokkaido. Moreover, the flowering scale has been reported to range from several tens to 20,000 ha (Makita 1998). Its occupation in Korean national parks may be comparable, even though we have not been able to measure the scale.

The five national parks we explored are geographically separated. Nevertheless, there was a phenomenon of synchronized flowering. What caused this rare unique event? The answer to this is unclear, and there have been several hypotheses regarding it, such as a biological clock (Janzen 1976), cytokine control (Nadgauda et al. 1990), environmental stresses such as drought (Lowrie 1900), and/or a combination of these (Franklin 2004). Cho et al. (2017) supported the stress hypothesis that the drought may have triggered the flowering of S. borealis, similar to this study. In fact, the droughts in the spring of 2014 and 2015 were severe in the northern region (Mun and Lee 2015; Park et al. 2015). At that time, most of the patches in Mt. Seorak were flowered. The values were very high compared to that of Mt. Jiri. Another drought event occurred in 2017. More patches flowered in Mts. Jiri and Deogyu in that year than in Mt. Seorak. Despite the drought in 2017, the reduced flowering in Mt. Seorak may have been because most of the patches $(74 \%)$ had flowered before that year, resulting in not many non-flowering patches remaining.

Park and Choi (2017) claimed that the flowering of $S$. borealis may be triggered by a specific gene that is periodically expressed in a biological clock, regardless of external environmental factors. This is because spring drought has occurred frequently in the past. Additionally, in Japan, S. borealis flowered in a large scale in 2016. In addition, flowering has been synchronized in recent years, with a peak being experienced in 2015. S. borealis would have settled more than several hundred years at least, although we do not know how long it had maintained on this land. If so, the population in Korea may be a complex of patches of different

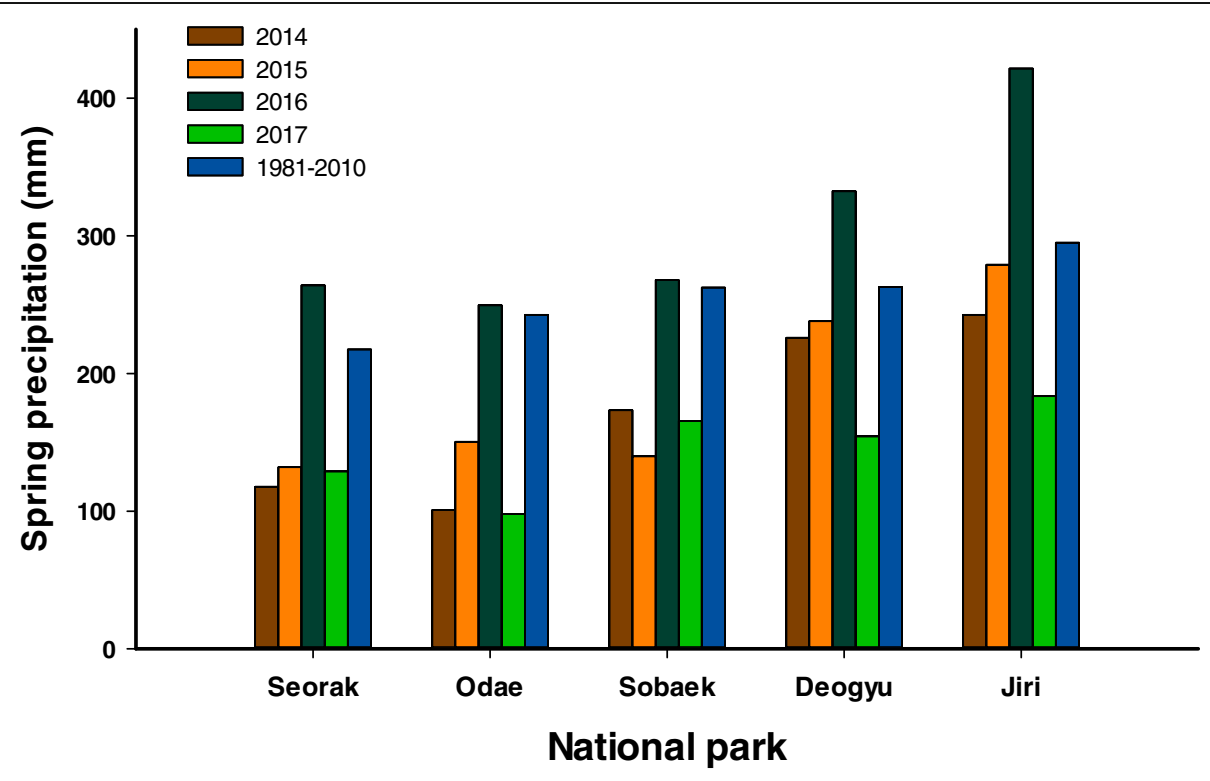

Fig. 6 Springtime precipitation between February and May in five national parks 


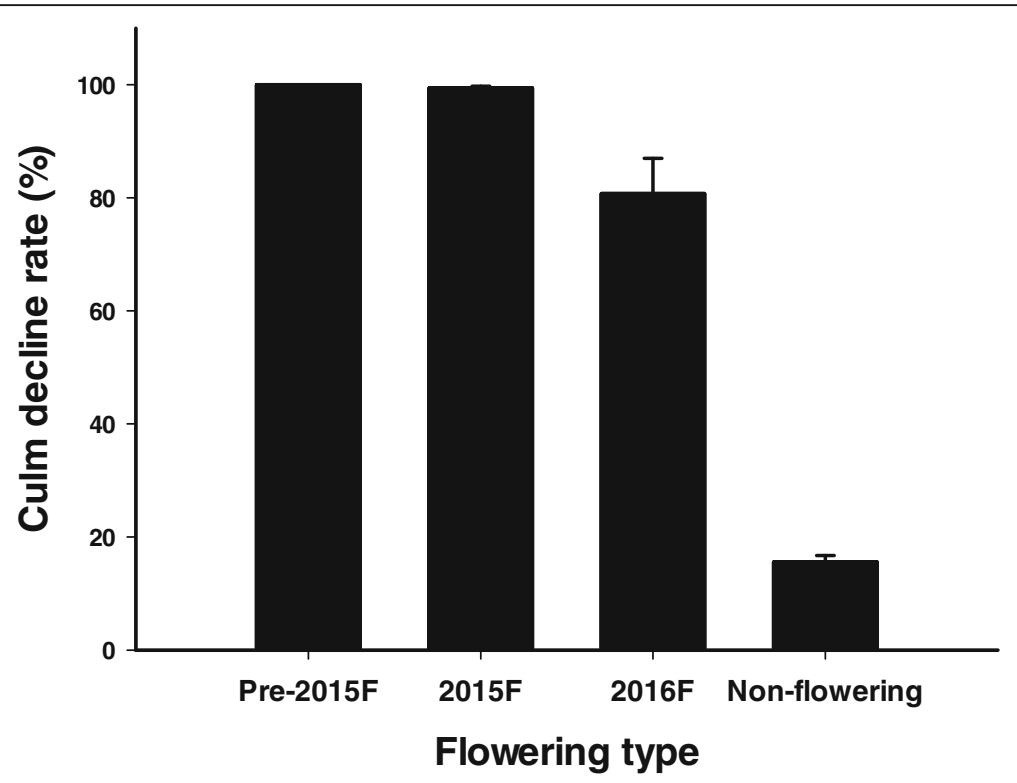

Fig. 7 Culm decline rate after flowering in five national parks. Values are means \pm standard errors

biological ages. Therefore, it is difficult to make the assumption that the flowering was controlled by the same biological clock for the patches of different ages in the separated national parks. We found that patches with larger culms that were sufficiently mature were reproduced. Taken together, it is more reasonable to assume that flowering and drought are related. The specific mechanism of flowering requires further research.

A few culms, $0.9 \%$, also flowered at the non-flowering patches, commonly along sunny trails. This could reflect sporadic flowering of a minority of culms in the culm population (Yamazaki and Nakagoshi 2005; Abe and Shibata 2014). S. veitchii var. hirsute showed sporadic flowering before and after mass flowering (Abe and Shibata 2012). It could be caused by the fact that one patch has been composed of multiple genets so that it had more than one flowering schedule, like the Bambusa arnhemica (Kaneko et al. 2008).

The flowering of Sasa species was considered to be important for the regeneration of forest (Nakashizuka 1988; Abe et al. 2001). This is because other suppressed species by Sasa could be regenerated if they declined after flowering (Taylor and Zisheng 1988; Makita 1992). The decline of $S$. borealis could have effects, such as creating gaps in forests. This could be an opportunity for buried seeds and/or for the advanced regeneration of the surrounding vegetation. Qian et al. (2016) stated that due to dense culms, the incoming seeds were effectively hidden, thus positively affecting the seed retention of the tree species. In regards to that, the seed stored in the soil had a chance to regenerate quickly following the decline. Moreover, the decline of S. kurilensis led to an increase in the survival of
Acanthopanax sciadophylloides, Fagus crenata, F. lanuginosa, Kalopanax pictus, and Sorbus commixta, as well as the emergence of Acer japonicum, F. crenata, Fraxinus lanuginosa, and Tilia japonica (Abe et al. 2002).

In order to expect these effects, the dieback of the flowered culms should be assumed soon after flowering. Sasa quelpartensis, distributed in Jeju Island, had massive flowering of $770 \mathrm{~m}^{2}$ in 2017 (Northeastern Asia Biodiversity Institute 2017). However, it did not decline, so the effects of horse grazing and cutting are currently being investigated. However, in this study, S. borealis declined by $99 \%$ of culms in the 2015F and Pre-2015F patches, while the culms in the $2016 \mathrm{~F}$ and $2017 \mathrm{~F}$ patches showed lower rates. This may be due to the process of declining or small-sized patches under $100 \mathrm{~m}^{2}$ being particularly slow, especially in Mt. Jiri.

\section{Conclusion}

We found that rare synchronized flowering of $S$. borealis occurred with a peak in 2015 nationwide. In addition, we determined that it not only monopolizes an enormous area, but also dominates the floor of the late-successional Q. mongolica-dominated deciduous forests. This is a major problem in Korean forests in that it has a tremendous impact on forest structures. The simultaneous decline following flowering could be an opportunity for forest regeneration, which means the natural control of this problematic species, S. borealis. On the other hand, it may resettle by the massively produced seeds. Therefore, the long-term monitoring on the forest dynamics is needed. 


\section{Abbreviations}

2015F: Flowered in 2015; 2016F: Flowered in 2016; 2017F: Flowered in 2017; Pre-2015F: Flowered in pre-2015; SPSS: Statistical Package for Social Science

\section{Acknowledgements}

We thank Bokyung Choi for her assistance in the field and Dr. Jong-Hwan Lim for personal communication on the status of S. borealis in Mt. Gyebang.

\section{Funding}

This study was supported by the Basic Science Research Program through the National Research Foundation of Korea (NRF) funded by the Ministry of Education (C1013696-01-01) and Korea Ministry of Environment and National Institute of Ecology as National Long-Term Ecological Research Project (NIE-Strategy Research-2018-02).

\section{Availability of data and materials}

The datasets during and/or analyzed during the current study are available from the corresponding author on reasonable request.

\section{Authors' contributions}

SC, YK, and YC designed and carried out field experiments. SC analyzed the data and wrote the manuscript. $Y C$ reviewed and edited the manuscript. All the authors approved the manuscript.

\section{Ethics approval and consent to participate}

Not applicable.

\section{Consent for publication}

Not applicable.

\section{Competing interests}

The authors declare that they have no competing interests.

\section{Publisher's Note}

Springer Nature remains neutral with regard to jurisdictional claims in published maps and institutional affiliations.

Received: 6 November 2018 Accepted: 9 December 2018

Published online: 29 December 2018

\section{References}

Abe M, Izaki J, Miguchi H, Masaki T, Makita A, Nakashizuka T. The effects of Sasa and canopy gap formation on tree regeneration in an old beech forest. J Veg Sci. 2002;13:565-74

Abe M, Miguchi H, Nakashizuka T. An interactive effect of simultaneous death of dwarf bamboo, canopy gap, and predatory rodents on beech regeneration. Oecologia. 2001;127:281-6.

Abe Y, Shibata S. Spatial and temporal flowering patterns of the monocarpic dwarf bamboo Sasa veitchii var. hirsuta. Ecol Res. 2012;27:625-32.

Abe $Y$, Shibata S. Flower and seed production in a series of flowerings from sporadic events before to after mass flowering of the dwarf bamboo Sasa veitchii var. hirsuta. J For Res. 2014;19:268-75.

Cerny T, Dolezal J, Janecek S, Srutek M, Valachovic M, Petrik P, Altman J, Song JS. Environmental correlates of plant diversity in Korean temperate forests. Acta Oecol. 2013;47:37-45.

Cerny T, Kopecky M, Petrik P, Song JS, Srutek M, Valachovic M, Altman J, Dolezal $J$. Classification of Korean forests: patterns along geographic and environmental gradients. Appl Veg Sci. 2015;18:5-22.

Cheon K, Chun J, Yang H, Lim J, Shin J. Change of understory vegetation structure for 10 years in long-term ecological research site at Mt. Gyebang. J Korean Forest Soc. 2014;103:1-11.

Cho S, Lee B, Choung Y. Rare nationwide synchronized massive flowering and decline event of Sasa borealis (Hack.) Makino in South Korea. J Plant Biol. 2017:60:423-30.

Cho S, Lee K, Choung Y. (2018). Distribution, abundance, and effect on plant species diversity of Sasa borealis in Korean forests. J Ecol Environ. 2018; 42:72-6

Franklin DC. Synchrony and asynchrony: observations and hypotheses for the flowering wave in a long-lived semelparous bamboo. J Biogeogr. 2004;31: 773-86.

Harper JL. Population biology of plants. London: Academic Press; 1977.
Hong W, Hu XS, Wu CZ, Yan SJ, Feng L, Lin YM. Comparison study on community structure features of the mixed forest of Phyllostachys pubescences in Fujian Province. J Plant Resour Environ. 2004;13:37-42.

Ito $H$, Hino T. Dwarf bamboo as an ecological filter for forest regeneration. Ecol Res. 2007;22:706-11.

Janzen DH. Why bamboos wait so long to flower. Annu Rev Ecol Syst. 1976;7:347-91.

Kaneko S, Franklin DC, Yamasaki N, Isagi Y. Development of microsatellite markers for Bambusa arnhemica (Poaceae: Bambuseae), a bamboo endemic to northern Australia. Conserv Genet. 2008:9:1311-3.

Korea Meteorological Agency. 2017. http://www.kma.go.kr. Accessed 31 Dec 2017.

Lee WT, Lim Y. Plant geography. Chuncheon: Kangwon National University Press; 2002. (in Korean)

Liu S, Zhou GM, Bai SB. Light intensity changes on Cunninghamia lanceolata in mixed stands with different concentrations of Phyllostachys pubescens. J Zhejiang A \& F Univ. 2011:28:550-4.

Lowrie AG. Effects of the late drought in the Chanda District. Indian Forester. 1900;26:504-6.

Makita A. Survivorship of a monocarpic bamboo grass, Sasa kurilensis, during the early regeneration process after mass flowering. Ecol Res. 1992;7:245-54.

Makita A. Population dynamics in the regeneration process of monocarpic dwarf bamboos, Sasa species. In: Cheplick GP, editor. Population biology of grasses. Cambridge: Cambridge University Press; 1998. p. 313-32.

Mun J, Lee D. Drought status of multi-purpose dam using year 2014 and 2015 water supply capacity index. J Korean Water Resour Assoc. 2015;48:51-7 (in Korean).

Nadgauda RS, Parasharami VA, Mascarenhas AF. Precocious flowering and seeding behaviour in tissue-cultured bamboos. Nature. 1990;344:335-6.

Nakashizuka T. Regeneration of beech (Fagus crenata) after the simultaneous death of undergrowing dwarf bamboo (Sasa kurilensis). Ecol Res. 1988;3:21-35.

Nakashizuka T, Numata M. Regeneration process of climax beech forests: I. Structure of a beech forest with the undergrowth of Sasa. Japanese. J Ecol. 1982;32:57-67.

Narukawa Y, Yamamoto S. Effects of dwarf bamboo (Sasa sp.) and forest floor microsites on conifer seedling recruitment in a subalpine forest, Japan. For Ecol Manag. 2002;163:61-70.

Northeastern Asia Biodiversity Institute. Study for management system of Sasa quelpaertensis. Jeju: World Heritage Office; 2017.

Oshima Y. Ecological studies of Sasa communities. I Productive structure of some of the Sasa communities in Japan. Bot Mag Tokyo. 1961;74:199-210.

Park M, Jang S, Kim S. Analysis of 2015 drought in Korea using real-time drought index. J Korean Soc Hazard Mitig. 2015;15:451-8 (in Korean).

Park S, Choi S. Why does draft bamboo bloom once in a lifetime on a large scale and then die? Korean J Environ Ecol. 2017;31:564-77.

Park SG, Yi MH, Yoon JW, Sin HT. Environmental factors and growth properties of Sasa borealis (Hack.) Makino community and effect its distribution on the development of lower vegetation in Jirisan National Park. Kor. J Env Eco. 2012;26:82-90 (in Korean).

Qian F, Zhang T, Guo Q, Tao J. Dense understory dwarf bamboo alters the retention of canopy tree seeds. Acta Oecol. 2016;73:38-44.

Qian H, Ricklefs RE. A comparison of the taxonomic richness of vascular plants in China and the United States. Am Nat. 1999;154:160-81.

Qian H, Ricklefs RE. Large-scale processes and the Asian bias in species diversity of temperate plants. Nature. 2000;407:180-2.

Shen R, Bai SB, Zhou GM, Wang YX, Wang N, Wen GS, Chen J. The response of root morphological plasticity to the expansion of a population of Phyllostachys edulis into a mixed needle-and broad-leaved forest. Acta Ecol Sin. 2016:36:326-34.

SPSS. IBM SPSS statistics for windows, version 23.0. Armonk: IBM Corp; 2016.

Taylor AH, Zisheng Q. Regeneration patterns in old-growth Abies-Betula forests in the Wolong natural reserve, Sichuan, China. The Journal of Ecology. 1988;76: 1204-18.

Wada N. Dwarf bamboos affect the regeneration of zoochorous trees by providing habitats to acorn-feeding rodents. Oecologia. 1993;94:403-7.

Yamamoto SI, Nishimura N, Matsui K. Natural disturbance and tree species coexistence in an old-growth beech-dwarf bamboo forest, southwestern Japan. J Veg Sci. 1995;6:875-86.

Yamazaki K, Nakagoshi N. Regeneration of Sasa kurilensis and tree invasion after sporadic flowering. Bamboo J. 2005;22:93-103.

Yang QP, Wang B, Guo QR, Zhao GD, Fang K, Liu YQ. Effects of Phyllostachys edulis expansion on carbon storage of evergreen broad-leaved forest in Dagangshan Mountain, Jiangxi. Acta Agric Univ Jiangxiensis. 2011;33:529-36. 